\section{SHRIMP PASTE "TERASI" VOLATILE COMPOUNDS FROM NORTHERN COAST OF CENTRAL JAVA}

Retno Murwania*, Hera Surya Adhi Putrab, Henggar Widiyantob, Agus Triantoa,b, Ambariyantoa,b

aNatural Product Laboratory, Centre of Research and Services Diponegoro University, Indonesia

bDepartment Marine Science, Faculty of Fisheries and Marine Science, Diponegoro University, Semarang, Indonesia
Article history

Received

11 November 2015

Received in revised form

18 December 2015

Accepted

23 February 2016

*Corresponding author rmurwani@gmail.com

\section{Graphical abstract}

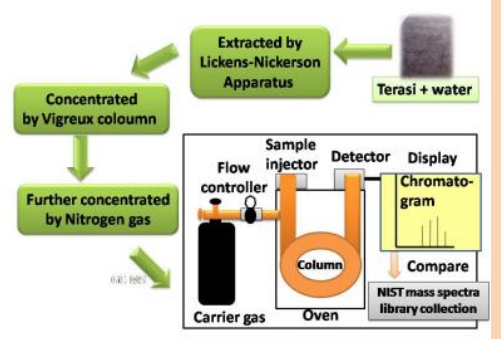

\begin{abstract}
A study was conducted to identify the composition of volatile compounds from traditional fermented shrimp called 'terasi'. Terasi samples were collected from six regions of northern coast of Central Java, Indonesia namely Pekalongan, Batang, Kendal, Demak, Jepara, and Pati. Mass spectral interpretation showed that terasi from these regions could be identified to contain a total of 102 volatile compounds. Terasi from Pekalongan, Batang, Kendal, Demak, Jepara, and Pati, each contained nine, 21, 10, 29, 12, and 21 volatile compounds respectively. There were four similar volatile compounds from Demak, Jepara and Pati samples, and two distinctive off odor in all six regions.

Keywords: Fermented shrimp, northern coast of Central Java, terasi, volatile compounds
\end{abstract}

\subsection{INTRODUCTION}

Fermented shrimp or shrimp paste well known as terasi is one of traditional processing of fishery products in Indonesia. Terasi is made from fermented shrimp with or without salt addition. However fish or a mixture of shrimp and fish can also be used depending on the availability or season. Terasi has reddish brown to blackish brown color depending on the raw materials and the naturally occuring microbes which involve during fermentation. Fresh terasi has a strong distinctive smell or odor which upon heating or cooking terasi releases volatile compounds. Exposure to such food odor produces appetizing response which can promote food intake [1, 2]. Terasi has been used for centuries as a flavor enhancer in many kinds of dishes and the released odor produce appetite for consuming the associated terasi flavored foods which can lead to satiety. Therefore terasi has been playing significant role in ensuring adequate food intake for centuries. Terasi from different production regions have similar but not the same odor as a result of processing variety such as length of sun exposure for drying and of fermentation time. It is the aim of this study to identify terasi volatile compounds produced at the centre of traditional terasi production in northern coast of Central Java i.e. Pekalongan, Batang, Kendal, Demak, Jepara, and Pati.

\subsection{EXPERIMENTAL}

Terasi were collected from six regions in the northern coast of Central Java namely Demak Jepara, Pati (Juwana), Pekalongan, Batang and Kendal. Terasi was collected from traditional small scale producers. Extraction of volatile compounds was carried out by mixing terasi sample with distilled water (1:5) and placed in Lickens-Nickerson apparatus. An internal standard of $0.1 \mathrm{~mL}$ was added. The sample was heated in a boiling water bath for $2 \mathrm{~h}$ after which it was extracted with $50 \mathrm{~mL}$ of diethyl ether at $40^{\circ} \mathrm{C}$. After extraction the remaining water was eliminated by addition of sodium sulphate anhydrous [3]. 
The extract was concentrated using Vigreux column to obtain $1 \mathrm{~mL}$ volume [4]. Finally it was further concentrated by nitrogen gas to obtain a final volume of $0.1 \mathrm{~mL}$ to $0.2 \mathrm{~mL}$ and $0.1 \mu \mathrm{L}$ was injected into GC-MS (Hewlett Packard). GC-MS was equipped with an HPWax column of $30 \mathrm{~mm}$ long, $0.25 \mathrm{~mm}$ diameter, and $2.56 \mathrm{~mm}$ thickness. Helium as the gas carrier was flowed at $1 \mathrm{~mm} \mathrm{~min}^{-1}$ at 3 bar (1 bar $=100000 \mathrm{~Pa}$ ) The interface and injection temperature was $230^{\circ} \mathrm{C}$. Temperature program was set at initial temperature of $70{ }^{\circ} \mathrm{C}$ for $1 \mathrm{~min}$ and $10^{\circ} \mathrm{C}$ per min increase until the final temperature of $230{ }^{\circ} \mathrm{C}$ was achieved. The electron energy of mass spectrometry was $1.2 \mathrm{kV}, \mathrm{Mr}$ range of 33 to 400 , and 0.5 second interval [5]. Mass Spectral Interpretation was done with the aid of a computer program to compare the patterns of mass spectra of compounds with a pattern of mass spectra in the National Institute of Standards and Technology mass spectra library collection. The collection has more than 62000 patterns of mass spectra [6].

\subsection{RESULTS AND DISCUSSION}

The chromatogram of GC-MS results were identified based on the retention time and the area of the peaks. Mass spectral interpretation of the peaks were identified by comparing them to pattern of mass spectra in the NIST mass spectra library collection. Table 1 showed the results of each class of volatile compounds in each sampling location. Terasi from Demak, Jepara, Pati, Pekalongan, Batang and Kendal could be identified to contain a total of 102 volatile compounds. The identified volatiles can be grouped into hydrocarbon, carbonyls, sulfur, alcohols, nitrogens, fatty acid, and ester compounds which showed similarities with others studying volatiles chemicals of shrimp or fish paste [7-9]

Terasi from Demak, Jepara, Pati, Pekalongan, Batang and Kendal each contained 29, 12, 21, nine, 21 , and 10 volatile compounds, respectively. Terasi from Demak showed 10 hydrocarbon, four carbonyls, one sulphur, seven alcohols, five nitrogens, a fatty acid, and an ester. Terasi from Jepara showed four hydrocarbon, a sulphur, two alcohols, two nitrogen, two fatty acids, and an ester compounds. Terasi from Pati showed seven hydrocarbons, a carbonyl, two sulphurs, four alcohols, five nitrogens, and a fatty acid compounds. Terasi from Pekalongan showed four hydrocarbon, one carbonyls, three alcohols, and a nitrogen compounds.

Terasi from Batang showed four hydrocarbon, three carbonyls, two sulfur, five alcohols, five nitrogen, a fatty acid, and an ester compounds. Terasi from Kendal showed two hydrocarbon, a carbonyl, three alcohols, three nitrogen, and a fatty acid compounds. Terasi from Demak, Jepara, and Pati showed four same volatile compounds i.e hexadecane, 1,11dodecadiene, dimethyl trisulfide, and indole, while Terasi from Pekalongan, Batang and Kendal showed three same compounds i.e Hexadecane, phenols, and indoles. The hexadecane and indole which give terasi off odor consistently found in samples from the six regions.

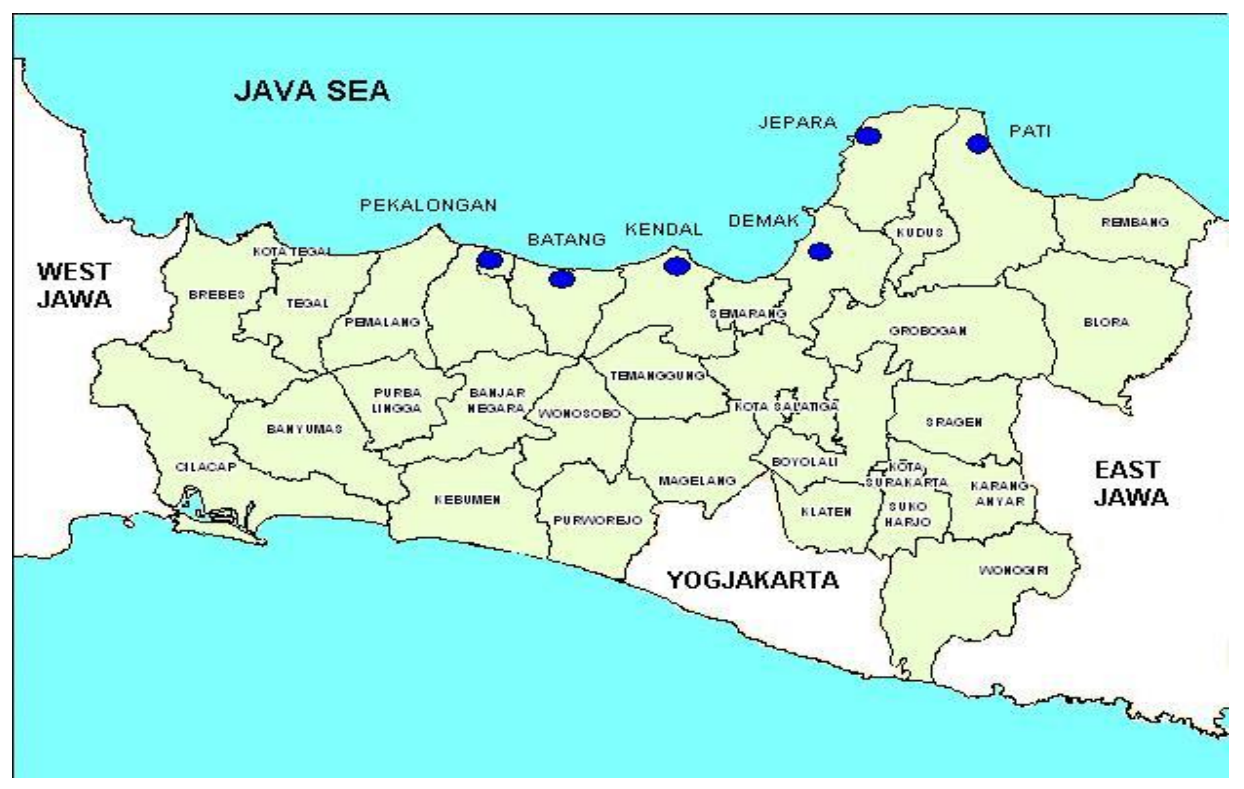

Figure 1 Map of the the six regions where terasi samples were collected ( 0 ) 
Table 1 Volatile compounds of terasi samples from Demak, Jepara, Pati, Pekalongan, Batang, and Kendal

\begin{tabular}{|c|c|c|c|c|c|c|c|}
\hline & \multirow{2}{*}{$\begin{array}{l}\text { Volatile compounds dectected } \\
\text { and identified } \\
\text { by GC-MS }\end{array}$} & \multicolumn{6}{|c|}{ Terasi from six regions of northern coast of Central Java } \\
\hline & & Demak & Jepara & Pati & Pekalongan & Batang & Kendal \\
\hline & Hydrocarbons & & & & & & \\
\hline 1 & Hexadecane & + & + & + & + & + & + \\
\hline 2 & 1,4-Octadiene & - & - & - & + & - & - \\
\hline 3 & 7-hexadecane & - & + & + & + & + & - \\
\hline 4 & 1,11-Dodecadiene & + & + & + & + & - & - \\
\hline 5 & 2-Methylbutylidene 2-phenylethyl & - & - & + & - & + & + \\
\hline 6 & 1-Docen-3-yne & - & - & - & - & + & - \\
\hline 7 & Cyclododecane & - & + & - & - & - & - \\
\hline 8 & 3-Tetradecene & + & - & + & - & - & - \\
\hline 9 & 1.3-cyclooctadicene & + & - & - & - & - & - \\
\hline 10 & 1-Pentadecene & + & - & + & - & - & - \\
\hline 11 & Cyclotetradecene & + & - & - & - & - & - \\
\hline 12 & Cyclodecene & + & - & - & - & - & - \\
\hline 13 & 1,2-dimethyl cyclooctane & + & - & - & - & - & - \\
\hline 14 & Bicyclo [2.2.1] heptane & + & - & - & - & - & - \\
\hline 15 & 1.4-cyclononadiene & - & - & + & - & - & - \\
\hline \multirow[t]{3}{*}{16} & 2- metoxy naphthalene & + & - & - & - & - & - \\
\hline & SubTotal & 10 & 4 & 7 & 4 & 4 & 2 \\
\hline & Carbonyl & & & & & & \\
\hline 17 & $5 z, 8 z, 11$-tetra-decatrien -2-one & + & - & - & + & + & - \\
\hline 18 & Butyl hidroxytolvene & - & - & - & - & + & + \\
\hline 19 & $\begin{array}{l}\text { 2-Hydroxy-4, 6-Cyclooctadien-1- } \\
\text { one }\end{array}$ & - & - & - & - & + & - \\
\hline 20 & 2-Undecanon & + & & & & & \\
\hline 21 & 2-Tridecanon & + & - & - & - & - & - \\
\hline 22 & 1-Finil-Ełenon & + & - & - & - & - & - \\
\hline 23 & Benzaldehyde & - & - & + & - & - & - \\
\hline \multirow[t]{3}{*}{24} & 3,4,5-methyl Cyclopentene-1-on & - & - & + & - & - & - \\
\hline & SubTotal & 4 & & 1 & 1 & 3 & 1 \\
\hline & Sulphur & & & & & & \\
\hline 25 & Dimethyl trisulfide & + & + & + & - & + & - \\
\hline 26 & Ethane, 1,2-bis (Methylthio) & - & - & - & - & + & - \\
\hline \multirow[t]{3}{*}{27} & Dinonil trisulfide, isomer mix & - & - & + & - & - & - \\
\hline & SubTotal & 1 & 1 & 2 & 0 & 2 & 0 \\
\hline & Alcohol & & & & & & \\
\hline 28 & Phenol, 2,6-bis (1,1-dimethylethyl) & + & - & + & + & - & - \\
\hline 29 & Phenol & + & - & + & + & + & + \\
\hline 30 & 1-Pentadecanol & - & - & - & + & - & - \\
\hline 31 & 3-Heptanol, 3,5-dimethyl & - & - & - & - & + & - \\
\hline 32 & 1,3-Benzenediol, 5-methyl & - & - & - & - & + & - \\
\hline 33 & 1-Tetradecanol & - & - & - & - & + & - \\
\hline 34 & 11-Hexadecen-1-ol & - & - & - & - & + & - \\
\hline 35 & Eugenol & - & - & - & - & - & + \\
\hline 36 & 1-Hexadecanol & - & - & - & - & - & + \\
\hline 37 & Phenyl ethyl alcohol & - & + & - & - & - & - \\
\hline 38 & 2.2-oxibis Ethanol & - & + & - & - & - & - \\
\hline 39 & 4-methyl phenol & + & - & + & - & - & - \\
\hline 40 & 1-Heptadecanol & + & - & - & - & - & - \\
\hline 41 & 1-Octadecanol & + & - & - & - & - & - \\
\hline 42 & p-Mentha-1 (7), 8 (10)-dien-9-ol & + & - & - & - & - & - \\
\hline 43 & $9,12,15$-octadeca-trien-1-ol & + & - & - & - & - & - \\
\hline \multirow[t]{3}{*}{44} & Mentionol & - & - & + & - & - & - \\
\hline & SubTotal & 7 & 2 & 4 & 3 & 5 & 3 \\
\hline & Nitrogen & & & & & & \\
\hline 45 & Indole & + & + & + & + & + & + \\
\hline 46 & $\begin{array}{l}\text { 1-Phenyl-2- } \\
\text { methylenaminopropane }\end{array}$ & - & - & - & - & + & - \\
\hline 47 & 2,5-dimethyl pyrazine & - & - & - & - & + & - \\
\hline 48 & 2 - (2-hydroxyethyl) piperidine & - & - & - & - & + & - \\
\hline
\end{tabular}


Table 1 continued

\begin{tabular}{|c|c|c|c|c|c|c|c|}
\hline & \multirow{2}{*}{$\begin{array}{l}\text { Volatile compounds dectected } \\
\text { and identified } \\
\text { by GC - MS }\end{array}$} & \multicolumn{6}{|c|}{ Terasi from six regions of northern coast of Central Java } \\
\hline & & Demak & Jepara & Pati & Pekalongan & Batang & Kendal \\
\hline 49 & $\begin{array}{l}\text { 2-Phenyl-N-benzylidine } \\
\text { ethylamine }\end{array}$ & - & - & - & - & + & - \\
\hline 50 & 3-Phenyl pyridine & - & - & - & - & - & + \\
\hline 51 & $\mathrm{~N}$-(2-Feniletil), Asetamide & - & - & - & - & - & + \\
\hline 52 & 2.6-dimethyl-3-N-butilpyrazine & + & - & - & - & - & - \\
\hline 53 & 2.6-dimethyl pirazin & + & - & - & - & - & - \\
\hline 54 & 2,5-dimethyl-3-(3-methyl) Pirazin & - & - & + & - & - & - \\
\hline 55 & 4-Phenyl Piridine & + & - & - & - & - & - \\
\hline 56 & 4-methyl-2-phenyl pyrimidine & + & - & - & - & - & - \\
\hline 57 & Benzeamine & - & - & + & - & - & - \\
\hline 58 & 1-Benzeneetamine, N-(Fenilmetil) & - & - & + & - & - & - \\
\hline \multirow[t]{3}{*}{59} & 5-metiloxiindol & - & - & + & - & - & - \\
\hline & SubTotal & 5 & 2 & 5 & 1 & 5 & 3 \\
\hline & Fatty acid & & & & & & \\
\hline 60 & 1,2 Benzene-dicarboxylic acid & - & + & - & - & + & - \\
\hline 61 & $\begin{array}{l}\text { Butanoic acid, 3-methyl, 2- } \\
\text { phenyl }\end{array}$ & - & - & - & - & - & + \\
\hline 62 & Pentanoic acid & - & + & - & - & - & - \\
\hline 63 & Hexadecanoic acid & + & - & - & - & - & - \\
\hline \multirow[t]{3}{*}{64} & Tetradecanoic acid & - & - & + & - & & \\
\hline & SubTotal & 1 & 2 & 1 & - & 1 & 1 \\
\hline & Ester & & & & & & \\
\hline 65 & Hexadecanoic acid, Methyl ester & - & + & - & - & - & - \\
\hline 66 & Ethyl linoleic & + & - & - & - & - & - \\
\hline \multirow[t]{3}{*}{67} & Ethyl laurate & - & - & - & - & + & - \\
\hline & SubTotal & 1 & 1 & 0 & 0 & 1 & 0 \\
\hline & Total & 29 & 12 & 21 & 9 & 21 & 10 \\
\hline
\end{tabular}

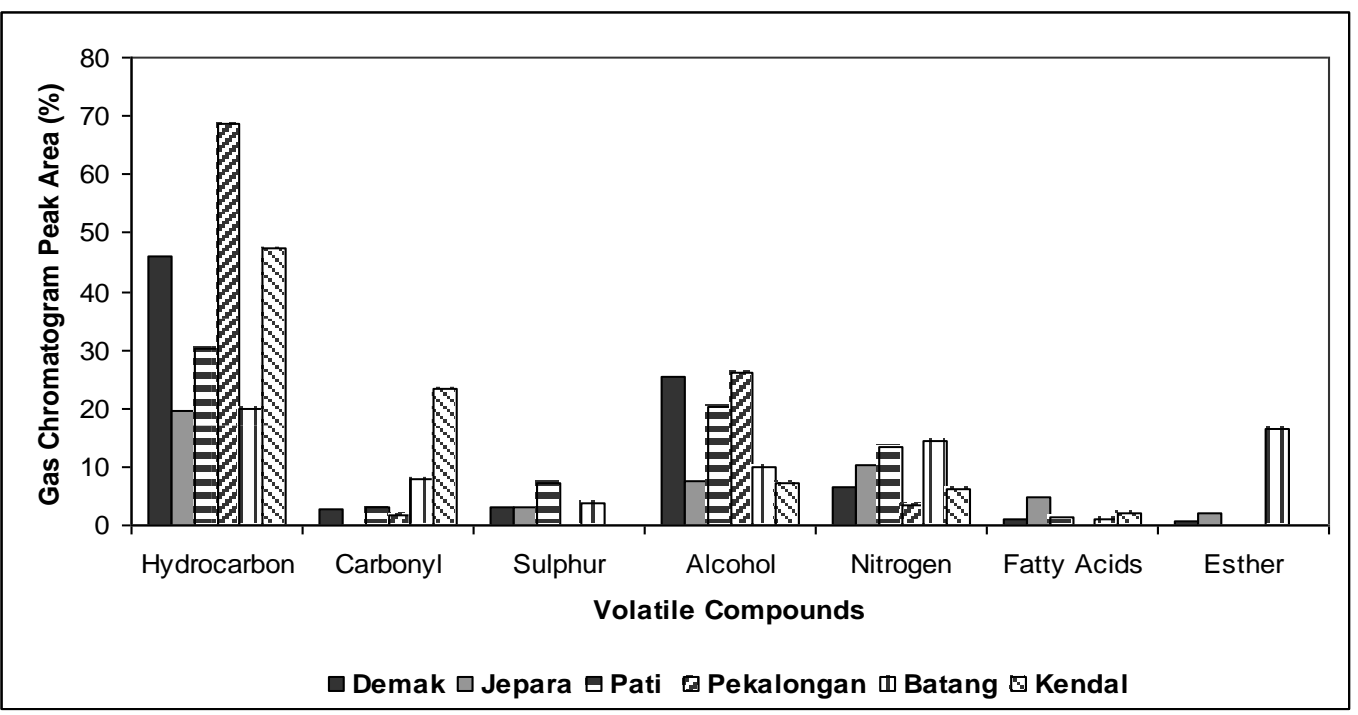

Figure 2 Chromatogram peak area (\%) of each class of terasi volatile compounds in each sampling regions

Figure 2 shows that the largest total peak area of hexadecane was found in sample from Pekalongan. Hexadecane was formed during fermentation in which lipids were oxidized into fatty acids by microbial activities. Fatty acids were subsequently converted into other compounds one of which is a hydrocarbon The highest total percentage area of carbonyl compounds was found in samples from Kendal (23.45 \%). Carbonyl compounds were also derived from lipid oxidation by microbial activities which produced distinctive scent of fermented shrimp. Carbonyl compounds could also be 
produced by non-enzymatic browning due to astaxanthin, the red pigment found in shrimp as the raw material. The pigments changed to brown color upon heating such as sun drying. Non-enzymatic browning enhanced the aroma and taste of a product. In samples from Jepara no carbonyl compounds were detected.

Sulphur compounds in shrimp paste was produced by enzymatic or heat protein degradation. The same sulfur compounds detected from samples of Demak, Jepara, Pati and Batang were dimethyl trisulphide, while none was detected in samples from Pekalongan and Kendal. In general, sulphur compounds of shrimp paste was very small, however they are quite strong and important. This was due to small threshold of sulphur compounds compared to the threshold of other volatile compounds [10]. The presence of sulfur compounds in shrimp paste gave the distinctive strong aroma of the product and therefore the strongest aroma of Terasi was found in samples from Pati.

Alcohols identified from Pekalongan terasi samples had the greatest percentage peak area compared to five other locations. Phenol were the same alcohols found in five locations. Phenol could be produced by lipids oxidation, sugar, and protein degradation. Protein degradation produced amino acids and peptides which were further broken down into other components such as hydrocarbons, esters and alcohols [10].

Indole as nitrogen compound identified in terasi samples from the six locations is an interesting volatile compound. It is interesting as it also found in jasmine and pork liver. Indoles in high concentration is well known as a typical off odor associated with putrefaction or fecal contamination, however no $E$. coli was found in all samples [11]. In contrast, when indole was combined in a very low concentration with other flowery chemical odor such as jasmine it would give depth to the existing aromas [10]. Nitrogen compounds was produced from the breakdown product of protein by the action of proteolitic bacteria during fermentation or the reaction of ammonia or amino acids with reducing sugars $[9,11]$. The highest total percentage area of nitrogen compounds was found from Batang and the smallest from Pekalongan. So samples from Batang would have stronger odor compared to samples from five other regions.

Fatty acid compounds were not found from Pekalongan samples. The largest total percentage area of fatty acid compounds were found from Jepara samples. Fatty acid compounds were produced from microbial enzymatic degradation of lipid [12]. The volatile fatty acids often lead to acidity in the aroma of terasi. Therefore terasi from Jepara has the most acidic odor compared with the other five regions.

Ester compounds in Terasi samples from Pati, Pekalongan, and Kendal were not found. The largest total percentage area of ester compounds in Terasi was found from Batang and the smallest one was found from Demak. Ester compounds was produced by the reaction between alcohol and a carboxylic acid salt which was catalyzed by esterase released by microbial fermentation.

The processing steps in traditional terasi making was in principle the same. Shrimp was washed and sun dried for a day or more depending on the sun light intensity. The dry shrimps were pounded manually and salt could be added, mixed, and dried further. In the afternoon when the sun has already set, the dried shrimp was kept indoor. The next day, it was pounded again and sun dried. After alternate sun drying and pounding, the product was molded and wrapped in banana leaves or plastic and kept for several days or more or even up to $4 \mathrm{wk}$ to let fermentation takes place. The final product was named terasi or known as shrimp paste. The product from each region showed variation on the number and peak area of volatile compounds. The three regions were located at the eastern part of Central Java and 3 others at western part (Figure 1). The locations have different ecological setting so that shrimps catch in those regions could have different characteristics. This combines with different processing namely length of sun drying, quantity of added salts, and length of fermentation time would give different fermentation process which consequently produces different microbial and enzymatic activities. These together would produce different degree of degradation products which contributed to different degree of volatile compounds typical of each region. We had record of processing procedure of terasi samples from three regions i.e Pekalongan, Batang, Kendal. The processing of sample from Pekalongan, Batang and Kendal were basically the same as described previously. However, terasi made in Pekalongan was added with salt and food color, Batang without added salt, and Kendal was also added with salt but no color. Together with the previous results which showed that terasi from Batang had higher number of total volatile compounds (21) compared to Pekalongan (9) and Kendal (10), this was more likely related to the processing without added salt. Shrimp paste processing (fermentation) with no salt produced a higher number of volatile compounds compared to processing with salt addition. This possibility was corroborated by previously developed study regarding proteolytic bacteria [10]. It was found that maximal growth of mesophylic proteolytic bacteria from terasi was found at zero (0) concentration of salt.

Terasi either fresh or briefly heated before or after mixing with other ingredients can release their volatiles which give an appetizing effect from the aromas. The sense of smell or termed olfactory sensation occurs when odorant molecules bind to specific scent receptors in our nasal cavity. The receptors can detect thousands of volatile chemicals. Volatile chemical odorants found in this study may all bind to the scent receptors simultaneously and send olfactory sensations which 
produced appetite for the associated food intake. Food intake stimulates not only retronasal olfactory sensation but also the taste buds receptors found in mouth and gastro-intestine which ultimately send signals to brain and produce satiety [13]. For centuries, terasi has been used in various dishes and cooking, and most often mixed with chili, garlic, a pinch of salt, and palm sugar to yield a well known dish called Sambal. Sambal is a appetizing food which accompanying rice and other complementary food such as Tempe which therefore usually increase food intake and produce satiety.

\subsection{CONCLUSION}

Volatiles compounds of terasi from six regions of nothern coast of Central Java belongs to hydrocarbons, carbonyls, sulphur, alcohols, nitrogen, fatty acids, and esters. The combined number, types, and concentration of the volatile compounds are different from each region and produced distinctivesignature smell of the product.

\section{Acknowledgement}

This study was financially supported by Centre of Ethno Food and Medicine, Research Institute Diponegoro University for financial support. Technical assistance from Anantasia Indriani is deeply appreciated.

\section{References}

[1] Ramaekers, M. G., S. Boesveldt, G. T. Gort, C. M. M Lakemond, M. A. J. S. van Boekel, and P. A. Luning. 2014 Sensory-Specific Appetite is Affected by Actively Smelled Food Odor and Remains Stable Over Time in Normal-
Weight Women. The Journal of Nutrition. 144(8): 13141319.

[2] Ramaekers, M. G., S. Boesveldt, C. M. M. Lakemond, M. A J. S. van Boekeland, and P. A. Luning. 2013. Odor: Appetizing or Satiating? Development of Appetite During Odor Exposure Over Time. International Journal of Obesity. 38: 650-656.

[3] Kumara, B. 1999. Identifikasi "Character Impact Compound" Flavor Buah Kawista - (Feronia limona) [Identification of Character Impact Fruit Flavor Kawista Compound (Feronia limona). Thesis. Bogor: IPB. [Bahasa Indonesia].

[4] Larson, M. and L. Pool. 1990. Quick and Sample Extraction Method for Aroma Compound in Food Products. In Bessier, Y. and A. F. Thomas (eds). Flavour Science and Technology. Chicester: John Wiley and Sons.

[5] Fardiaz, D. 1989. Kromatografi Gas dalam Analisa Pangan [Gas Chromatography in Food Analysis]. Bogor: IPB. [Bahasa Indonesia].

[6] NIST. 2002. National Institute of Standards and Technology Standard Reference Database IA NIST/EPA/NIH Mass Spectral Library and NIST Mass Spectral Search Program.

[7] Cha, Y. J. and K. R. Cadwallader. 1995. Volatile Compounds in Salt-fermented Fish and Shrimp Pastes. Journal of Food Science. 60(1): 19-27.

[8] Li, C., J. WU, Y. Yan Li, and Z. Dai. 2013. Identification of the Aroma Compounds in Stinky Mandarin Fish (Siniperca chuatsi) and Comparison of Volatiles During Fermentation and Storage. International Journal of Food Science \& Technology. 48(11): 2429-2437.

[9] Pongsetkul, J., S. Benjakul, P. Sampavapol, K. Osako, and N. Faithong. 2015. Chemical Compositions, Sensory and Antioxidative Properties of Salted Shrimp Paste (Ka-pi) in Thailand. International Food Research Journal. 22(4): 1454-1465.

[10] Choi, N. E. and J. H. Han. 2015. How Flavor Works. The Science of Taste and Aroma. UK: John Wiley and Sons, Ltd.

[11] Murwani, R., Supriyadi, A. Subagio, Trianto, and Ambariyanto. 2015. Isolation and Identification of Thermophilic and Mesophylic Proteolytic Bacteria from Terasi. AIP Proceeding 2nd International Conference on Chemical and Material Engineering. 1699. (In Press).

[12] Surono, I. S. and A. Hosono. 1994. Chemical and Aerobic Bacterial Composition of "Terasi", a Traditional Fermented Product from Indonesia. Journal of the Food Hygienic Society of Japan. 35(3): 299-304.

[13] Moyer, M. 2015. What Makes Food Taste So Good? Scientific American. 24(2): 4-8. 